\title{
Eurostudia
}

\section{Remembering the Romanian Anti-Communist Armed Resistance: An Analysis of Local Lived Experience}

\section{Monica Ciobanu}

Volume 10, numéro 1, 2015

From Today's Observation Post: Collaboration and Resistance under Communism

Vues du poste d'observation du présent : collaboration et résistance sous le communisme

Kollaboration und Widerstand im Kommunismus - Betrachtungen aus heutiger Sicht

URI : https://id.erudit.org/iderudit/1033884ar

DOI : https://doi.org/10.7202/1033884ar

Aller au sommaire du numéro

Éditeur(s)

Le Centre canadien d'études allemandes et européennes

ISSN

1718-8946 (numérique)

Découvrir la revue

Citer cet article

Ciobanu, M. (2015). Remembering the Romanian Anti-Communist Armed Resistance: An Analysis of Local Lived Experience. Eurostudia, 10(1), 105-123. https://doi.org/10.7202/1033884ar
Résumé de l'article

The anti-communist armed resistance that occurred as a disparate and heterogeneous movement in Romania from 1944 until 1962 became a highly politicized topic after 1989. Some interpreted this history as an element of the national resistance against Soviet occupation and the ensuing forced communization. Others demonized the partisans (or at least minimized their role) and presented them as outlaws, fascists, and criminals. This essay analyzes the armed resistance and its place within the politics of memory from three interrelated perspectives: 1) as lived experience in the context of post-World War II emergence of communism; 2) it takes a concretely localized perspective; and 3) analyzes these lived experiences as they have been presented in autobiographical accounts heavily influenced by post-1989 anti-communist rhetoric. The article concludes that multiple histories of repression and resistance have so far tended to be incorporated in a master narrative and argues that an approach emphasizing localized lived experience may offer an alternative interpretative framework.
Tous droits réservés $@$ Le Centre canadien d'études allemandes et européennes, 2015
Ce document est protégé par la loi sur le droit d'auteur. L'utilisation des services d'Érudit (y compris la reproduction) est assujettie à sa politique d'utilisation que vous pouvez consulter en ligne.

https://apropos.erudit.org/fr/usagers/politique-dutilisation/ 


\title{
Monica Ciobanu
}

State University of New York, Plattsburgh

\begin{abstract}
:
The anti-communist armed resistance that occurred as a disparate and heterogeneous movement in Romania from 1944 until 1962 became a highly politicized topic after 1989. Some interpreted this history as an element of the national resistance against Soviet occupation and the ensuing forced communization. Others demonized the partisans (or at least minimized their role) and presented them as outlaws, fascists, and criminals. This essay analyzes the armed resistance and its place within the politics of memory from three interrelated perspectives: 1) as lived experience in the context of post-World War II emergence of communism; 2) it takes a concretely localized perspective; and 3) analyzes these lived experiences as they have been presented in autobiographical accounts heavily influenced by post-1989 anti-communist rhetoric. The article concludes that multiple histories of repression and resistance have so far tended to be incorporated in a master narrative and argues that an approach emphasizing localized lived experience may offer an alternative interpretative framework.
\end{abstract}

Undoubtedly what has been called anti-communist armed resistance in both academic literature and popular culture in Romania represents one of the most fascinating, contested, and romanticized topics in the history of Romanian communism and the post-communist politics of memory. ${ }^{1}$ Hundreds of articles published in daily newspapers, weekly journals, literary magazines, and many

\footnotetext{
${ }^{1}$ The anti-communist armed resistance became the catch-all term to describe geographically disparate groups engaged in open confrontations with the communist authorities between 1944 until 1962 in Romania. It is important to distinguish it from civilian forms of opposition to Soviet-type communization of the country that involved the forced collectivization of agriculture, the dismantling of private property and the elimination of political pluralism. This distinction was made by Dobrincu (2006) and Bejenaru (2003).
} 
academic — especially historical—studies and books have been written on this topic. The question at the center of this brief essay is the following: How can we overcome the understanding of this theme as presented exclusively from the angle of a post-1989 dismantling of a collective memory manufactured under communism in order to situate it in the context of the politics of the present? ${ }^{2}$ Since the politics of the present in an emerging democracy is strongly interconnected with the issue of coming to terms with the past we can ask: What conceptual framework can we employ in order to examine a highly politicized historical episode that goes beyond the re-telling of historical myths and the (re)construction of earlier sources of identity and legitimacy?

I see three interrelated ways of proposing an alternative but complementary analysis of the memorialization of armed resistance. The first is to examine this history as concrete lived experience. This involves departing from official or public accounts of the armed resistance that aim towards its integration within a master narrative of communism. Instead, the actions of those involved either directly or indirectly in the armed resistance should be analyzed in a post-World War II context characterized by widespread violent repression and abrupt communization of the country. Second, a localized or situational perspective on the armed resistance needs to be employed, one that highlights more subtle and complex relationships within local communities. The local/ regional context allows us to distinguish different counter-memories of the communist repression. The third way is an analysis of such lived experiences (available as they are in published form as oral histories, autobiographical accounts or memoirs) as individual biographies that reflect changing positions in a world in which new values, norms, and ideologies are prescribed and enforced.

\section{Images of the Armed Resistance: from Adulation to Vilification}

If we start with the positive characterizations of the armed resistance, we can distinguish several representations conducive to a myth of an anti-communist and anti-Soviet heroic national movement. A variety of mass-media outlets,

\footnotetext{
${ }^{2}$ See Lavinia Stan (2013) for her discussion of the relationship between the politics of memory and the politics of the present and Monica Ciobanu (2014) for her analysis of the memorialization of the armed resistance after 1989 in the context of ongoing struggle for political legitimacy between former communists and anti-communist actors.
} 
including television documentaries, weekly journals, and daily newspapers described the partisans as heroes, individuals with exceptional or even superhuman qualities who enjoyed widespread support and loyalty within their communities. ${ }^{3}$ Some historians have gone so far as to argue that had external circumstances been different, and had the Western powers not permitted the Soviet Union to incorporate Eastern European countries (including Romania) into its sphere of domination, the armed resistance could had led a successful war of national liberation from the USSR (Boldur-Lăţescu 2004; Ciuceanu 1996). To some degree, such accounts have been endorsed by civic associations and former dissidents attempting to oppose and challenge the pervasive dominance of the heirs to the Communist Party (PCR) in public life in the 1990s and early 2000s. ${ }^{4}$ For some, this was a way of legitimizing their own anti-communist credentials that consisted primarily in disparate and isolated acts of dissidence in the late 1970s and 1980s brave though they were. ${ }^{5}$ As Aurora Liiceanu argues, the glorification of resistance became instrumental in bolstering national pride (Liiceanu 2003: 13). Although presented in a more subtle manner, the section devoted to the history of the anti-communist armed resistance in the report issued by the Presidential Commission for the Analysis of the Communist Dictatorship in Romania concludes that this historical episode is part of a recent past that can and should be integrated in collective national memory that, otherwise, has few such moments and phenomena to which it can connect (Tismăneanu, Dobrincu, Vasile 2007: 680). ${ }^{6}$

\footnotetext{
${ }^{3}$ The popular TV documentary Memorialul Durerii produced in the early 1990s by the journalist LuciaHossu Longin devoted several episodes to the armed resistance. Quite frequently, hyperbole is used in order to present the courage and patriotism of the partisans and their supporters. Articles published in the daily Jurnalul National and in the Memoria: Revista Gîndirii Arestate (a magazine released in 1990 by the Writers' Union that documents the communist repression) also cast a romantic light on this topic.

${ }^{4}$ The most active association engaged in the memorialization of the communist repression has been the Civic Academy Foundation led by the well-known former dissident and public intellectual Ana Blandiana. Many former partisans and their supporters had been invited to lecture at the summer School of Memory organized by the Foundation since 1997 at the Sighet Memorial. For the work of the Sighet Memorial, see http:/ / memorial.sighet.ro, accessed on July 25, 2015.

${ }^{5}$ For a comprehensive analysis of the role of the dissidents in late communist Romania, see Cristina Petrescu (2013). The title of her book, From Robin Hood to Don Quixote: Resistance and Dissent in Communist Romania, is suggestive.

6 The Presidential Commission for the Analysis of the Communist Dictatorship in Romania was established in April 2006 by President Traian Băsescu and was led by the well-known Romanian-born American political scientist Vladimir Tismăneanu. Although it was not endorsed by the legislature, it issued an almost 700-page report that condemned the communist regime as illegal and criminal. For the
} 
In respect to negative images of the armed resistance, we can distinguish a spectrum of interpretation that ranges from outright demonization of the partisans and their actions to mere trivialization. In fact, as Florin Banu (2006: 268-269) has accurately emphasized, such accounts were made possible by the weaknesses of those very analyses that have idealized the armed resistance. Former officials and members of the repressive apparatus of the secret police, Securitate, as well as sympathizers and supporters of the old regime labeled these clandestine groups and their members as at best fascist, criminal, or anti-national elements subordinate to foreign Western interests seeking to destabilize the country. ${ }^{7}$ Others, including former Securitate general Nicolae Pleşiţă, dismissed the armed resistance as an isolated phenomenon rooted in the local traditions of the southern-central Argeş region of an outlaw vigilante life-style (Viorel Patrichi 2001: 86).

Although the romanticized version is more dominant in public representations in reality both accounts are biased. Well-documented historical research indicates the heterogeneous make-up of the partisan groups. In terms of political affiliation, among them were members and sympathizers of the historical parties (the National Liberal Party, PNL and the National Peasant Party, PNT, ), the Iron Guard Movement as well as communists. ${ }^{8}$ Although such partisan groups led a clandestine life in many geographical regions, there was no real coordination between them. In fact, the role of the National Resistance Movement (MNR) - a movement involving leaders of the main historical parties seeking to preempt the Soviet take-over in 1946 which was connected to Western embassies and governments-has been wildly exaggerated. Raluca Nicoleta Spiridon (2006: 335-365) shows that at the time, the governing authorities themselves orchestrated the trial of the MNR in order to intimidate the historical parties before the November 1946 elections. Some former partisans themselvesincluding Ion Gavrilă Ogoranu, Gavrilă Vatamaniuc, Lucreţia Jurjacknowledged after 1989 that they never posed a real threat to the regime and

work of the commission and its significance for coming to terms with the past see Lavinia Stan (op. cit) and Monica Ciobanu (2009).

${ }^{7}$ Former General Neagu Cosma (1994) labels in his memoirs the partisans as fascist. Similarly, General Alexandru Nicolschi (1992), who orchestrated the capturing of partisans by creating "fake bands" in the 1950's, expressed the same verdict.

${ }^{8}$ See Budeancă, Olteanu, and Pop (2006), Dobrincu (2007, 2009), Onişoru (2003), Doru et al (2003). 
that their role was rather limited in maintaining an anti-communist climate in their local communities in the event of an American intervention. ${ }^{9}$

\section{The Armed Resistance as Lived Experience}

For more than five decades, the communist regime attempted to erase from public memory all symbols or artifacts of the pre-communist era. Or, as occurred in many cases, party-state propaganda incorporated them in an all-inclusive ideology of a socialist order that promoted in the 1970s and 1980s a strongly nationalist ideology. In this account, the pre-World War II capitalist order was unfair, unjust, and corrupt. The repression of the late 1940s-1950s was an unfortunate but necessary phase that eventually ceased with the Declaration of Independence of 1964 promulgated by Gheorghe Gheorghiu-Dej, the secretary of the Communist Party. ${ }^{10}$ After 1989, a reverse trend took shape. The memory explosion that emerged in the early 1990s resulted in hundreds-possibly thousands-of autobiographical accounts in which the suffering and inhuman treatment of former political prisoners, deportees, and their families in the gulag was vividly described. These accounts became instrumental in the production of a version of the communist past as repressive, inhumane, and alien. Ultimately, it resulted in a unique pattern of remembering that excluded alternative voices (Tileagă 2012; Petrescu and Petrescu 2014). For most social actors, however, who were neither directly persecuted nor part of the repressive apparatus, communism was a reality that meant adjustment and accommodation to the challenges of daily life (Gallinat 2009; Todorova and Gille 2012).

So, what does lived experience mean for former partisans, their supporters, families, neighbors and communities? To answer this question, we need to free ourselves from the conventional dualism of interpretations which present the groups of partisans either as guided by patriotic, anti-Soviet, and anti-communist beliefs and in which the communist authorities are seen as subordinate to an external occupation or as traitors. Instead, we can look beyond the spectacular, heroic, dramatic or less praiseworthy aspects of the history of the

\footnotetext{
${ }^{9}$ See Ion Gavrilă Ogoranu's memoirs (2009), an interview with Gavrilă Vatamaniuc in Dobrincu (2006: 279-289), Gavrilă Vatamaniuc and Octavian Fornica (2003: 114-133) and Lucreţia Jurj's testimony in Jurju and Budeancă (2002).

${ }^{10}$ For nationalist-communist propaganda, see Katherine Verdery (1991).
} 
armed resistance and try to comprehend the daily challenges of the clandestine life of the partisans and their effects.

The various motives that led partisans to adopt such a clandestine existence-a life of deprivation (food, shelter) and the ongoing prospect of being hunted by the authorities-suggest that in many cases joining the resistance was not necessarily a free or politically motivated choice. Although there was a small but significant number of former middle and high-ranking officers who had some vision of military action against the Soviet occupation (including Gheorghe Arsenescu, Nicolae Dabija, Toma Arnăuţoiu, Ioan Uţa), a majority of partisans ended up as outlaws in order to escape the repressive constraints of the new regime. Some, including officers who fought alongside Germany during the war, former legionaries, and members of the rural bourgeoisie who were leaders of the local branches of the historical parties were motivated to avoid arrest and probable incarceration or death. ${ }^{11}$ Others, principally representing a segment of the wealthy and mid-ranking peasantry, were in the resistance to avoid the compulsory deliveries and quotas of agricultural produce to the state or to avoid, as especially was the case of Greek Catholics, religious persecution. Finally, some found themselves in hideouts because of kinship or patrimonial loyalties or, as a result of being singled out by the authorities for providing support to the partisans. ${ }^{12}$ It should, however, be mentioned that at the time anti-communism and anti-Sovietism was prevalent in the country.

Becoming an outlaw meant not just being involved in a continuing guerilla-type war with the local military or the police, but also to be in a state of permanent trepidation of potential betrayal by fellow partisans, family members, or supporters. In fact, once the authorities realized that military force alone was ineffective in dismantling these groups, subtler strategies were employed engaging village and town inhabitants for this purpose. The most common approach was the cooptation of informers from among local residents of the area

\footnotetext{
${ }^{11}$ See Dobrincu (2009), Ogoranu (2009), Voicu-Arnăuţoiu (2009).

${ }^{12}$ For the relationship between the armed resistance and the forced collectivization of agriculture, see Kligman and Verdery (2011). Mungiu (2010) shows how, in the case of the Arnăuţoiu group, social status differentials were maintained during clandestine existence. Also, it is important to note that a few women partisans-Maria Plop, Lucreţia Jurj, Aristina Săileanu, and Maria Jubleanu—followed their husbands, lovers, or fathers into hiding.
} 
in which the partisans were operating and the infiltration of moles into partisan groups themselves.

The diary of the so-called "lonely partisan," (Vasile Motrescu, found by Securitate in 1955 in his hideout) is quite revealing in this regard. Motrescu was one of the first partisans who joined the anti-Soviet resistance in 1944 as Soviet troops were entering Bukovina in the northeastern part of the country. From 1944 until 1955, Motrescu was part of several groups that operated in Bukovina. ${ }^{13}$ On several occasions Securitate tried to use him as an agent in order to arrest two wanted men, Vatamaniuc and Ogoranu, but he always derailed their plans and never betrayed his fellow fugitives. Between 1955, when in an open encounter with government forces he and Vatamaniuc killed three soldiers, and 1958 when he was executed, Motrescu led a solitary life. This diary is unique and the most valuable of documents as it describes Motrescu's inner struggles, doubts, fear, and anger when facing hunger, cold weather, rejection by his wife and other family members as well as the ongoing prospect of being captured and sentenced. In the diary he states that "other partisans are the best friends of other partisans, but also the worst traitors" (cited in Baranu and Bărbulescu 2006: 157). Besides maintaining a diary, he also sent several letters to the local authorities. These letters-like the diary-contained threats and criticism of the regime's policies of communization but also attempted to negotiate his surrender. In sum, we seem to be dealing here with a conscience very much in conflict.

Mistrust among partisans was not uncommon and in some cases resulted in vigilante killings for alleged betrayals. The most relevant cases involve two of the most well-known and equally controversial groups. These are the Arnăuţoiu and the Şuşman groups. ${ }^{14}$ After 1989, both were celebrated by the public but also-not at all surprisingly—became controversial targets of hatred and distrust

\footnotetext{
${ }^{13}$ For the armed resistance in Bukovina, see Dobrincu (2004).

${ }^{14}$ The Arnăuţoiu group was set up in 1949 in the Argeş region and initially included brothers Toma and Petre Arnăuţoiu and Colonel Arsenescu. Because of tactical disagreements the group split shortly after. The Arnăuţoiu brothers, together with 14 other men who supported them, were executed after their arrest in 1958. Arsenscu was arrested in 1960 and subsequently executed. The Şuşman group emerged in Răchiţele village located near the city of Cluj, the capital of Transylvania. Teodor Şuşman (a former mayor of Răchiţele) had refused to join the PCR. Since 1948, he and his two sons Visalon and Teodor, together with six others became fugitives. The group was annihilated in 1958 after the two brothers died during an open stand-off with the authorities. Similarly, harsh prison sentences and executions followed. It is important to note that both families represented the bourgeois class of their respective local communities and enjoyed high status and political influence.
} 
in their local communities. We will return to this problematic issue later in the article. Some participants, witnesses and descendants with knowledge of these incidents expressed significant reservations in respect to accusations of betrayal. This was particularly the case of Petre Purcel who was executed by the Şuşmans for his own alleged betrayal of the group. Some historians (Dobrincu 2006), as well as descendants of Purcel, believe that it was an error. In his testimony, Cornel Drăgoi (a member of the Arnăuţoiu-Arsenescu group who was arrested and imprisoned until 1962 for his activities against the regime) expressed regret when discussing the fate of the men executed by the Arnăuţoiu brothers (Nicolau and Niţă 2012: 163-164). Drăgoi suggested that Darie Banu was in reality attempting to deceive the police and appear as an informer. Given that there have been several documented cases of double agents, these accounts are quite credible. ${ }^{15}$ Even more revealing is that ambivalence or even complicity with the partisans was also manifested among some members of the local authorities as well. Former partisans (including Lucreţia Jurj, Aristina Săileanu, Ion-Gavrilă Ogoranu) refer in their memoirs to incidents involving party officials offering food, shelter, or tipping off the partisans. Often times, mayors, policemen, or other local officials felt caught between loyalties to their kinsmen or fellow villagers and the PCR.

These examples show that the line between heroes and traitors or victims of communism and their perpetrators is never quite clear cut. The history of the armed resistance as lived experience represents something more than a life and death battle between partisans and Securitate forces. The partisans and their supporters were neither heroes as presented by the post-communist rhetoric of anti-communism nor "bandits" as crudely portrayed by official propaganda under communism and their detractors after 1989. The line between these two extreme characterizations is often blurred. They were simply individuals who faced extraordinary circumstances and who found they had no recourse but to make difficult and uneasy choices to cope with the new political and economic

\footnotetext{
${ }^{15}$ We have already presented the case of Vasile Motrescu. Banu (2006: 322) discusses the case of a Vasile Rafailă who managed to deceive Securitate officers. In fact, he was in permanent contact with Securitate and provided information about his collaboration with the authorities to the group led by Leon Şuşman, the same group he was to inform on. Reports issued by the Ministry of Internal Affairs (MAI) during the 1950s also acknowledge that many of the informers or agents recruited in order to capture these groups were unreliable and provided false information about the partisans' whereabouts (CNSAS, File no. 8600, vol. 2, Bandele din regiunea Cluj).
} 
realities confronting them. The same was the case for rural communities, which responded to the abrupt and painful processes of communization and collectivization with mixed reactions of resistance, accommodation, acquiescence, and collaboration to the new regime. We now turn our attention to the many conflicting accounts of remembrance in these communities.

\section{A Localized View of the Armed Resistance}

The manufacturing of the communist past by political actors and also civil society organizations such as Civic Alliance and the Group for Social Dialogue has been shaped by the politics of the present and the varying needs for selflegitimation of these actors. According to their own logic, to be integrated into the Western democratic world the non-democratic past must be emphatically and completely repudiated. Since the early 2000s, Romanian political elites had subordinated the official politics of memory to the quest for accession into the European Union by establishing links of historical continuity with Western democratic values and traditions. ${ }^{16}$ In contrast, vernacular images and subjectified memories of the past do not fit into this logic. As Young and Light show "within their everyday lives many people may remember socialism in a more ambivalent and nuanced manner. Such local memories can constitute a form of 'counter-memory': practices of remembrance that are out of alignment with the efforts of the state to shape and define the remembrance of the socialist era" (Light and Young 2015b: 221). Thus, notions of resistance, collaboration, or repression tend to be perceived non-ideologically. Such forms of understanding are equally rooted in long-term allegiances, conflicts, and personal dynamics within given communities.

In such small rural areas as Nucşoara (the native community of the Arnăuţoiu family) or in the Răchiţele village of the Şuşmans, the role of partisans is assessed in more complex terms. Local recollections of armed resistance do not at all conform to the dualistic moral characterizations of communism and resistance to its official version. In fact, many inhabitants felt that the ongoing conflict between Securitate forces and local partisan groups was no more than a tragic episode in their lives with no wider meaning. They had been permanently

\footnotetext{
${ }^{16}$ For a systematic presentation of the relationship between the politics of memory in the area of urban space and the process of European integration, see Light and Young (2015a).
} 
terrorized by threats, searches, interrogations, fear of arrest, and torture. In consequence, some reacted in angry rejection or opposition to the partisans. In one instance, Ion Bandea (the last lone wolf partisan from the Banat region) was killed in 1962 by inhabitants of the area in order to bring to an end the ongoing government persecutions to which they were subjected (Dobrincu 2006: 600).

The legacy of these events was long-lasting and their impact resented many decades later. Teofil Răchiţeanu, the son of Petre Purcel, who was executed by the Şuşmans, describes the partisans and Securitate as two malevolent forces that brought pain and misfortune to the villagers. ${ }^{17}$ With the help of Teodor Boc (the local priest from Rachiţele), Rachiţeanu attempted to develop a countermemory of the Şuşmans. In response to historical and journalistic accounts that portrayed Teodor Şuşman as a well-respected leader and figure in the village, they projected him as an unscrupulous individual who enriched himself and the family through fraud and exploitation of others (Răchiţeanu and Boc 2005). Similarly, Cornel Drăgoi expressed his resentment towards the Arnăuţoiu brothers. He charged that their arrest led to the persecution of many because of a diary found when they were captured that contained detailed information about their supporters (Nicolau and Niţă 2012: 133).

These ambivalent and often hostile accounts of the partisans were also rooted in deep-seated personal or family animosities and feuds that, in many cases, predated the communist regime. ${ }^{18}$ For example, villagers from Răchiţele remembered political and economic rivalries between two leading local families (the Paşcus and the Şuşmans), which persisted after the arrival of the communists and after Suciu Paşcu became the communist mayor of the village and took part in the repression that followed. Others reminisced about a decades-long and apparently never-ending conflict between the Boc and Şuşman families that had originally been triggered by an illicit love affair. ${ }^{19}$ Alina Mungiu

\footnotetext{
17 "Partizanii: Toader Şuşman, erou al luptei anticomuniste din Munţii Apuseni-între legendă şi adevăr," in Gardianul, September 19, 2009 (accessed at www.guardianul.ro/index_blank.php?pag+news, on July 23 2015).

${ }^{18}$ In fact, not just in Romania but elsewhere in Europe, the conflicts of World War II are traceable to histories that predated both the German or Soviet occupations. See Tony Judt (2000: vii-xii).

19 "Composesoratul Răchiţele, contestat de urmaşii luptătorilor anticomunişti Şuşman," Napoca News, October 6, 2009 (accessed at http://www.napocanews.ro/2009/10/exclusiv-composesoratul-rachitelecontestat-de-urmasi, on July 23, 2015).
} 
(2010) has shown that personalized conflicts caused by competition for resources in Nucşoara were also present both before the World War II and were to continue after 1989 over deeply felt issues of land redistribution. Here, as in Răchiţele, some of the participants and witnesses to the history of armed resistance expressed much more nuanced and diverse personal views about the partisans and their supporters. This was the case of Ana Simion, who felt uneasy about her involvement in supporting the Arnăuţoiu group, which had led to her imprisonment twice. She also believed that after 1989 others took sole credit for their role in the resistance while ignoring hers. ${ }^{20}$

This excursion into local forms of recollections of the past indicates that communism as lived experience is usually remembered in personalized and conflicting terms. In the case of the armed resistance, the repressive activity and nature of the regime does not necessarily coincide with a generally favorable view of the partisans. Nevertheless, when analyzing personal recollections such as these, we need to consider how stories change and often shift unconsciously from purely individualized accounts to include and express broader narratives shaped by the new external post-communist context and how these narratives are filtered and adapted to suit individual needs.

\section{Post-Communist Autobiographical Narratives}

Students of memory emphasize that individual processes of remembering are dynamic, ongoing, and selective. Thus, recollections of the past are filtered though particular current frameworks of remembering that reflect present social and political contexts. Maurice Halbwachs showed in his classic study On Collective Memory (see Coser 1994) that memories reproduced through successive biographical stages give individuals a sense of identity and belonging to a group. Following this line of argument, contemporary scholars point towards the relationships between remembering social and political changes and identity crises (Megill 2011; Assman and Shortt 2012). When systemic changes take place in society "we change our world views and our interpretations and reinterpretations of our biography as we move from one social world to another"

${ }^{20}$ Cătălin Nedelcu, Interview with Ana Simion “O altfel de Elisabeta Rizea: povestea Anei Simion” (accessed at http:// memorial.sighet.ro/index.php?view=article\&catid=47\%3Abreviar-pentru-procesulcomunismului on July 24, 2015). 
(Berger 1963: 219). In other words, as ideologies, belief systems, principles and values change, we try to adjust our biographies accordingly. Certain events and episodes become significant in our lives while others are conveniently silenced. ${ }^{21}$

The breakdown of the communist regimes left East European societies with difficult legacies to overcome, the most inconvenient of which were the issues of guilt and complicity with their previous repressive governments (Olick 2007; Passerini 1992). In this context, it became imperative to identify heroes and role models who can connect the undemocratic past to a liberal democratic future. We can situate the re-discovery after 1989 of the anti-communist armed resistance in Romania in this context. Earlier in the essay we have made some references to the adulatory or at least romanticized manner in which some journalists, historians, and civic actors presented the lives and activities of the partisans. How this anti-communist rhetoric influenced the partisans' own sense of self after 1989 is crucial in understanding how changing social and political circumstances shape the mechanisms of remembering.

Many of the testimonies of those involved with the armed resistanceperhaps with the exception of the leaders-do not indicate clear ideological anticommunist views that led them to go outside the law (Ciobanu 2014: 1474-1475). For women like Lucreţia Jurj, Elisabetea Rizea, Aristina Săileanu, it was (at least initially) loyalty to family or spouse that put them in opposition to the regime. But after arrest, interrogation and then imprisonment the experience of being named "enemies of the regime" transformed them into politically stigmatized individuals. Until 1989, former political prisoners and their families were permanently constrained by threats from the authorities and experienced severely restricted life chances. ${ }^{22}$ After many years of silence, the fall of communism created a unique opportunity for former partisans and political prisoners to publicize their biographies and reclaim a rightful place in the

\footnotetext{
${ }^{21}$ In Post-Communist Life Writing and the Discourses of History: Vesna Goldsworthy's Chernobyl Strawberries (2009), Ioana Luca looks at how the use of memory and self-representation is relevant for understanding and rendering of historical moments. By using the case study of a Securitate informer, Cristian Tileagă (2011) examines how remembering can connect biography, memory and identity to the broader ideological context.

${ }^{22}$ In 1964 political prisoners were released in Romania. On release, they were asked to sign a document stating that they would not reveal any detail of their interrogation, arrest, and incarceration. They were also required to make periodical reports about their work and life to Securitate. Some caved in to these pressures and became informers. See Oprea (2003).
} 
emerging democratic society. But in a political context still dominated by former elites and the machinery of the Securitate in the 1990s and early 2000s, which persisted in trumpeting a nationalist-populist propaganda, former political prisoners were often viewed with skepticism or outright hostility. ${ }^{23}$ Again, as had once been the case with Stalinist propaganda, it became common to label them fascists or criminals. Many partisans or supporters of the armed resistance mention the jealousy of neighbors, acquaintances or friends at the modest compensatory measures to which they were now entitled as political prisoners. This second experience of victimization could only amplify their original anticommunist views and associate them with the post-communist and virulently anti-communist camp. Many of the old partisans and their descendantsincluding Ion Gavrilă Ogoranu, Gavrilă Vatamaniuc, Lucreţia Jurj, Aristina Săileanu, Elisabeta Rizea, Mihai Timaru, Ioana Raluca Voicu-Arnăuţoiu and others-became frequent guest-speakers at different public events organized by civic associations, cultural and academic institutions, and media outlets. But despite this spotlight thrown on them, they were not inclined to accept the flattering labels of heroes or role models very readily.

\section{Concluding Thoughts}

This short analysis of aspects of the memorialization of the armed resistance in post-1989 Romania leads us to several preliminary conclusions regarding the "historical remembrance" of repression, resistance and collaboration in early communism. ${ }^{24}$ Also, it opens some avenues for future research.

The presentation of the armed resistance as lived experience within localcommunity context illustrates that there is no single master narrative of repression and resistance to Soviet occupation and communization. Instead, we are led to distinguish individual or small group responses and coping strategies to the newly emerging post-World War II political reality. To a large extent, these

\footnotetext{
${ }^{23}$ For an analysis of the democratic transition and the role of former elites in shaping the process of democratization, see Tom Gallagher (2005).

${ }^{24}$ By using the concept of historical remembrance we embrace Jay Winter's explanatory framework of memory and history as being both familial and collective enterprises. Winter defines historical remembrance as "a discursive field extending from ritual to cultural work... it differs from family remembrance by its capacity to unite people... and yet historical remembrance has something of the familial and something of the sacred in it" (2006: 11).
} 
responses were shaped by the local context characterized by specific socioeconomic and interpersonal relationships. The examples we have used illustrate that, for the most part, communities were not simply divided between supporters of the armed resistance and those who collaborated with the authorities and were opposed to the partisans. Moreover, there is no clear convergence between the first group and what some commentators identify as opposition to communization and Sovietization. As shown here, the peace of these small rural collectivities was disrupted by both the repressive measures of Securitate and the threat of partisan retaliation to government forces and their betrayal. Many had to navigate between the two. How to negotiate family or kinship loyalties-kinship as understood in a broad sense and not restricted to blood ties-and issues of individual survival became in most cases a very real dilemma. How this complex and complicated history was remembered by those who participated in the armed resistance-either directly or indirectly as witnesses-was also partly filtered through experiences of the political upheaval in the anti-communist uprising of 1989. For those political actors and elements of civil society who opposed the revival of former elites, communism was quickly equated with repression and foreign occupation. It is thus understandable that post-communist autobiographical narratives and their representation in the public sphere placed emphasis on anti-communism-in many cases presented as principal patriotism - as a leading factor in the life experiences of the partisans and their supporters.

As a case study in the post-1989 memorialization of repression and resistance, the historical reconstruction of the role of partisan groups suggests a need for incorporating a local and sociological perspective. There are multiple histories of repression and resistance that tend to be incorporated in a diversified all-encompassing national narrative, which has been subordinated to political competition between the opposing factions or parties of former communists and anti-communists. By considering how individual and group memories are fluid and adjustable to a present context, researchers can avoid the temptation of becoming trapped in rigid classifications and categorizations. 


\section{Bibliography}

Assman, A. and L. Shortt (2012) (eds.). Memory and Political Change. New York: Palgrave Macmillan.

Banu, F. (2006). “Mişcarea de rezistenţă armată anticomunistă din România: între negare şi hiperbolizare" (The Romanian Anticommunist Armed Resistance Movement: between Dismissal and Hyperbole). In Rezistenţa Anticomunistă: Cercetare Ştiinţifică şi Valorificare Muzeală (The Anticommunist Resistance: Scientific Research and Museum Utilization) edited by C. Budeancă, F. Olteanu and I. Pop. Cluj-Napoca: Argonaout: 268-282.

Bara, G. (2009). “Composeratul Răchiţele, contestat de urmaşii luptătorilor anticomunişti Şuşman" (Răchiţele Common Property: Contested by the Descendants of Şuşman Anticommunist Fighters). Napoca News, (October 9). Accessed July 23, 2015. http://www.napoca.news.ro/2009/10/ exclusivcomposesoratul-rachitel-contestat-de-urmasi

Bejenaru, L. (2003). "Să lupţi pentru a muri" (To Fight and to Die). In Mişcarea armată de rezistenţă anticomunistă din România: 1944-1962 (The Anticommunist Armed Resistance in Romania: 1944-1962), edited by G. Onişoru. Bucharest: Kullusys: 367-399.

Berger, P. (1963). Invitation to Sociology: A Humanistic Perspective. New York: Anchor.

Boldur-Lăţescu, G. (2004). The Communist Genocide in Romania. New York: Nova Science Publishers, Inc.

Ciobanu, M. (2014). "Reconstructing the History of Early Communism and Armed Resistance in Romania." Europe-Asia Studies, 66(9): 1452-1481.

Coser, L. A. (1994) (ed.). Maurice Halbwachs: On Collective Memory. Chicago: Chicago University Press.

Ciuceanu, R. (1996). "Istoria ca un balast" (History as Curse). Arhivele Totalitarimsului, IX: 11-12.

Dobrincu, D. (2004). "Bucovinenii contra Sovietici: Rezistenţa Armată Antisovietică Anticomunistă din Bucovina (martie-august 1944 -iulie 1946)" (Bukovinians Against the Soviets: the Anticommunist Anti-Soviet Armed Resistance in Bukovina/March-August 1944 - July 1946). Anuarul Institutului de İstorie Orală, V: 124-183. 
- (2006). Rezistenţa Armată Anticomunistă din România: 1944- începutul anilor '60 (The Romanian Anticommunist Armed Resistance: 1944- the Beginning of the 1960's). PhD Thesis. Faculty of History, University of İaşi, Iaşi.

—. (2007). "Rezistenţa armată anticomunistă din Munţii Apuseni" (The Anticommunist Armed Resistance in the Apuseni Mountains). In School of Memory 2006 (Şcoala Memoriei 2006), edited by R. Rusan. Bucharest: Civic Academy Foundation: 240-272.

—. (2009). "Historicizing a Disputed Theme: Anti-Communist Armed Resistance in Romania." In Stalinism Revisited: The Establishment of Communist Regimes in East-Central Europe, edited by V. Tismăneanu. Budapest, New York: Central European Press: 284-305.

Gallagher, T. (2005). Theft of a Nation: Romania since Communism. London: C. Hurst \& Company.

Gallinat, A. (2009). "Intense paradoxes of memory: researching moral questions about remembering the socialist past." History and Anthropology, 20: 183199.

Judt, T. (2000). "Preface." In The Politics of Retribution in Europe: World War II and its Aftermath, edited by I. Deak, J. Gross, and T. Judt. New Jersey, Princeton: Princeton University Press: vii-xii.

Jurju, L. and C. Budeancă (2002). Suferinţa nu se dă la fraţi (You Cannot Transfer the Pain to Your Brothers). Cluj Napoca: Dacia.

Kligman, G and K. Verdery (2011). Peasants under Siege: The Collectivization of Romanian Agriculture. 1949-1962. Princeton: Princeton University Press.

Light, D. and C. Young (2015a). "Public Space and the Material Legacies of Communism in Bucharest." In Post-Communist Romania at 25: Linking Past, Present and Future, edited by L. Stan and D. Vancea. Lanham, Maryland: Lexington Books: 41-62.

—. (2015b). "Local and Counter-Memories of Socialism in Post-Socialist Romania." In Local Memories in a Nationalizing and Globalizing World, edited by M. Beyen and B. Deseure. Basingstoke: Palgrave Macmillan: 221-243.

Luca, I. (2009). "Post-communist Life Writing and the Discourses of History: Vesan Goldsworthy's Chernobyl Strawberries." Rethinking History. 13(1): 79-93. 
Megill, A. (1998). "History, Memory, and Identity." History of the Human Sciences, 11(3): 37-62

Mungiu, A. (2010). A Tale of Two Villages: Coerced Modernization in the East European Countryside. New York: Central European University Press.

Nedelcu, C. "O altfel de Elisabeta Rizea: Povestea Anei Simion; Interviu cu Ana Simion" (A different Elisabetea Rizea: The Story of Ana Simion; Interview with Ana Simion). Accessed July 24, 2015. http: / / memorial.sighet.ro/ index.php? view $=$ article\&catid $=47 \% 3$ Abreviar-pentru-procesulcomunismului

Nicolau, I. and T. Niţă (2012). Povestea Elisabetei Rizea din Nucşoara urmată de mărturia lui Cornel Drăgoi (The Story of Elisabeta Rizea of Nucşoara followed by Cornel Drăgoi's Testimony). Bucharest: Humanitas.

Ogoranu, I. G. (2009). Brazii se frîng dar nu se îndoaie (Trees can Break but do not Bend). Baia Mare: Marist.

Olick, J. K. (2007). The Politics of Regret: on Collective Memory and Historical Responsibility. New York: Routledge.

Onişoru, G. (2003). Mişcarea armată de rezistenţă anticomunistă din România: 19441962 (The anticommunist armed resistance in Romania: 1944-1962). Bucharest: Kullusys.

Oprea, M. (2003), Banalitatea răului. O istorie a Securităţii în documente (The Banality of Evil. A History of Securitate in documents). İaşi: Polirom.

Passerini, L. (1992) (ed.). Memory and Totalitarianism. Vol. 1. Oxford: Oxford University Press.

Patrichi, V. (2001). Ochii şi urechile poporului. Convorbiri cu Generalul Nicolae Pleşiţă (The People's Eyes and Ears. Dialogues with General Nicolae Pleşiţă). Bucharest: Lumea.

—. (2009). “Teodor Şuşman, erou al luptei anticomuniste din Munţii Apuseni: între legendă şi adevăr." (Teodor Şuşman: a Hero of the Anticommunist Resistance from the Apuseni Mountains: between Legend and Truth). Gardianul, September 19. Accessed July 23, 2015. www.guardianul.ro/ index _ blank.php?pag+news, on July 232015.

Petrescu, C. and D. Petrescu (2014). "The Canon of Remembering Romanian Communism." In Remembering Communism: Private and Public Recollections of Lived Experience in Southeast Europe, edited by M. Todorova, A. Dimou, 
and S. Troebst. Budapest and New York: Central European University Press: 29-42.

Petrescu, C. (2013). From Robin Hood to Don Quixote: Resistance and Dissent in Communist Romania. Bucharest: Editura Enciclopedică.

Radosav, D. \& al. (2003) (eds.). Rezistenţa Anticomunistă din Apuseni. Grupurile 'Teodor Şuşman,' 'Capotă-Dejeu,' 'Cruce şi Spadă' (The Anticommunist Resistance in the Apuseni. 'Teodor Şuşman', Capotă-Dejeu' and 'Cross and Sword' Groups). Cluj Napoca: Argonaut.

Răchiţeanu, T. and T. Boc (2005). Cazul Şuşman în judecata răchiţenilor (The Şuşman Case in Răchiţeni's Judgment). Cluj-Napoca: Casa de Editură Napoca.

Spiridon, R. (2003). “Consideraţii generale asupra unei legende: 'Mişcarea Naţională de Rezistenţă" (General Considerations Regarding a Legend: the National Resistance Movement). In Mişcarea armată de rezistenţă anticomunistă din România: 1944-1962 (The Anticommunist Armed Resistance in Romania: 1944-1962), edited by G. Onişoru. Bucharest: Kullusys: 335-365.

Stan, L. (2013). Transitional Justice in Post-Communist Romania. Cambridge: Cambridge University Press.

Tileagă, C. (2012). "Communism and the Meaning of Social Memory: Towards a Critical-Interpretive Approach." Integrative Psychological and Behavioral Science, 46(4): 475-492.

—. (2011). “(Re)writing Biography: Memory, Identity, and Textually Mediated Reality in Coming to Terms with the Past." Culture \& Psychology, 17(2): 197-215.

Tismăneanu, V., D. Dobrincu, and C. Vasile (2007) (eds.). Raport Final: Comisia Prezidenţială pentru Analiza Dictaturii Comuniste din România (Final Report: the Presidential Commission for the Analysis of the Communist Dictatorship in Romania). Bucharest: Humanitas.

Todorova. M and Z. Gille (2012) (eds.). Post-Communist Nostalgia. New York and Oxford: Berghahn Books.

Țăranu, L. and M. Dobre (2006) (eds.). Jurnale din Rezistenţa Anticomunistă: Vasile Motrescu, Mircea Dobre, 1952-1953 (Diaries from the Anticommunist Resistance: Vasile Motrescu, Mircea Dobre, 1952-1953). Bucharest: Nemira. 
Vatamaniuc, G. and O. Fornica (2004). "Destine în Rezistenţă" (Destinies of Resistance). Şcoala Memoriei 2003 (School of Memory 2003), edited by R. Rusan. Bucharest: Fundaţia Academia Civică: 114-133.

Verdery, K. (1991). National Ideology under Communism: Identity and Cultural Politics in Ceauşescu's Romania. Berkeley: University of California Press.

Voicu-Arnăuţoiu, R. (2009). Luptătorii din Munţi: Toma Arnăuţoiu Grupul de la Nucşoara. Documente ale Anchetei, Procesului, Detenţiei (The Partisans from the Mountains: Toma Arnăuţoiu Nucşoara Group. Documents of the Interrogation, Trial and Detention. Bucharest: Vremea.

Winter, J. (2006). Remembering War: the Great War between Memory and History in the Twentieth Century. New Haven and London: Yale University Press. 